\title{
Does Decentralized Leadership Influence the Performance of Czech Museums?
}

\author{
Michal Plaček ${ }^{1}$, František Ochrana ${ }^{2}$, Milan Pi̊ček ${ }^{3}$, Milan Kř́a Mk $^{4}$
}

\begin{abstract}
This study tests whether decentralized leadership influences the efficiency of running selected cultural institutions, specifically museums in the Czech Republic. For the analysis, data from 2015 from 187 museums spread around the whole Czech Republic are used. The method for the evaluation of efficiency is data envelope analysis, and for identifying the influence of decentralized leadership, a regression analysis is used. Museums established by municipalities reach higher efficiency than museums established by regions and central government. The causes may be found in the ability to better estimate the local demand as well as in the rational behavior of municipalities that prefer a cost-minimization strategy. The benefits of decentralization cannot be seen only in the field of finance but also in reinforcing local traditions, trust and the effects of social capital that is generated by a strong regional cultural identity.
\end{abstract}

\section{Keywords:}

decentralized leadership; cultural heritage; performance; DEA

Jel Classification: H11, H76, H77

1 Center for Social and Economics Strategies, Faculty of Social Sciences, Charles University, Prague, Czech Republic.

2 Center for Social and Economics Strategies, Faculty of Social Sciences, Charles University, Prague, Czech Republic.

3 National Museum of Agriculture, Prague, Czech Republic.

4 National Museum of Agriculture, Prague, Czech Republic. 


\section{Introduction}

Decentralized leadership describes a situation when local governments may realize their own public policy without the approval of central governments, e.g. education, health care, culture, etc. (Silva 2016). The basis of the concept of decentralization is described by Oates' theorem and Tiebout's hypothesis; these approaches are of course elaborated into newer and more complicated concepts (e.g. Silva 2014, 2015; Caplan et al. 2000). These concepts were followed by empiric studies which try to evaluate the impact of decentralization in various fields of provision of public services, e.g. in the fields of municipalities (Benito et al. 2010; Matějová et al. 2014; Soukopová et al. 2014) and health care (Atkinson and Haran 2004; Nemec et al. 2010). Other studies try to assess the impacts of decentralization in the context of reforms of the public sector in the spirit of New Public Management (Palermo and Wilson 2014; De Vries 2000; Marin 2015). Very few studies deal with impacts of this phenomenon in the field of cultural policy, to be more specific in the field of protecting the cultural heritage. Within the research, only a few studies by Baraldi and Shoup (2014) were identified that describe positive impacts of decentralization within the Turkish highly-centralized system of museums; however, they express concerns about the replicability of the whole process and sustainability. Shoup et al. (2014) on the example of Turkey also describe the possibility of economies of scale with the help of outsourcing secondary activities of museums, e.g. selling souvenirs and tickets. Darnel, et al., (1998) claim that local-authority museums have experienced a rapidly changing competitive environment. Shifts in cultural policy at the national and local levels have led to a higher emphasis on plural funding, customer orientation and management for efficiency and effectiveness. Detailed awareness of the demand from visitors may be the solution to this problem. Barrio and Herrero (2014) use data envelopment analysis to assess the effectiveness of museums. The main findings indicate that at least half of the museums chose to operate efficiently, with the major cause for inefficiency being inadequate resource management. In the researched sample, museums established by bigger towns did better. The abovementioned studies represent a more anecdotal approach to the problem, rather than a complex view.

The ambition of this study is to fill the vacuum between the theory and an empirical analysis, i.e. to test whether decentralized leadership influences the performance of museums. Decentralization in our case is understood as the establishment and operation of a museum at different levels of government as well as the ensuring of its funding. The basic tool is a model created with the help of data envelope analysis that involves economic as well as social indicators.

Subsequently, this model is modified, and it shows how the results of performance measurement change when the indicator of cost efficiency is omitted. The results are supplemented by structured interviews with selected managers of the museums. 


\subsection{Effectiveness as a part of the public-value concept}

With regard to the fact that the article focuses on the economy of cultural heritage - which is a very specific value - the authors decided to define the idea of effectiveness in a broader sense, using the public-value concept. The public-value concept as a boundary for strategic control in the public sector was brought into the scientific literature by Moore and Khagram (2004). In their understanding it is a strategic triangle which contains value (in the sense of being aimed at creating something substantively valuable), legitimacy and support (attracting sufficient ongoing support - and concomitant resources - from the authorizing environment), operationally and administratively feasible (doable with the available organizational and external capabilities needed to be produced; Alford and O'Flynn 2009). This concept is connected with a profound discussion between normative understanding, which says what the managers should do, and empiricism, which describes what in fact managers in the public sector do (Alford and O'Flynn 2009). According to Alford and O'Flynn (2009), public value focuses on a wider range of value than public goods and outputs, as well as on what has meaning for people, rather than what a public-sector decision-maker might presume is best for them. Commentators on this topic offer lists of values: equity, efficiency, fairness, justice, prudence, transparency, social cohesion, user orientation, political accountability, regime stability (Thompson and Rizova 2015). According to Thompson and Rizova (2015), many practitioners and some scholars appear to believe that government enterprises create public value in the same way business does - by increasing productivity, efficiency, and effectiveness. This view is nowadays associated with the New Public Management (NPM) (Thompson and Rizova 2015). Mazouz et al. (2016) confirm that effectiveness is a significant part of public value. An important function of the public-value concept is also the fact that it creates a boundary for the measurement of effectiveness. Authors (Thompson and Rizova 2015) claim that the Public Service Value methodology measures how well an organization, or series of organizations, achieves outcomes and cost-effectiveness year after year. The methodology gives public managers a way to evaluate the performance of an organization in relationship to the organization's average performance over a series of years.

In the authors' opinion, this suggests that effectiveness is a significant part of public value, i.e. that citizens apart from fulfilling their needs, in this case the need of protecting the cultural heritage, have the right to request that this activity be realized with the highest effectivity possible. However, in the field of cultural heritage, this is not a typical procedure. This is confirmed by Barrio and Herrero (2014), who in their literature research claim that the first studies focusing on the effectiveness of cultural institutions appeared a few years later than studies in other fields. The first concepts created were indicators, e.g. for a balanced scorecard or for benchmarking. Only later did parametric and non-parametric models such as DEA start to be used. Barrio and Herrero claim that of all institutions that deal with the protection of the cultural heritage, museums are the most analyzed entities, as there are studies from 
England, Italy, Spain, etc. However, this is not true for the Czech Republic, where for now benchmarking indicators of museums are not used. The first application of DEA in the Czech Republic was done by Plaček et al. (2016), who studied institutions established by the central government in 2014. When compiling indicators, they followed the methodology of Taheri and Ansari (2013) and Barrio et al. (2009, 259). The study revealed quite a large space for an increase of effectiveness of institutions established by the state. In the authors' opinion, this is a consequence of the fact that public value in countries in Central and Eastern Europe is a fuzzy concept (Nemec, et al., 2010). The vagueness of this approach is probably best illustrated by the definition of public value according to Rutgers (2015): be as good as it gets.

\section{Sector of museums in the Czech Republic}

The activity of museums in the Czech Republic since 2001 has been controlled especially by Act no. 122/2000 Coll., on Protection of Collections of Museum Nature. This act newly established standards of museum work, and it also defines the term "museum". It is good to give the definition of the International Council of Museums ICOM to compare with the definition of museums according to Act no. 122/2000 Coll. Both definitions work with a non-profit character of a museum, with the term "service". The definition according to the law works especially with the memory and educational function of a museum. The definition according to ICOM adds the word "pleasure", which relates to the experience function of a museum (Hájek et al. 2011). The definition of a museum by ICOM has 3 functions then, i.e. memory, educational (sometimes also called didactical) and experience. The three given functions of a museum do not exist separately - a typical feature of a product of a museum is its complex character. Apart from long- and short-term exhibitions, it also involves cultural or educational events, educational programs or a whole range of additional services.

The following tables provide a basic view of the situation in the museum sector in the Czech Republic. Table 1 shows the number of museums according to the establishers.

Table 1

Museums according to establishers

\begin{tabular}{|l|c|}
\hline \multicolumn{1}{|c|}{ Establisher } & Number \\
\hline State museums & 27 \\
\hline Regional museums & 94 \\
\hline Municipal museums & 257 \\
\hline Other establishers & 111 \\
\hline Total & 489 \\
\hline
\end{tabular}

Source: NIPOS (2016) 
The table shows an evident influence of decentralization in the Czech Republic, which was more a consequence of attempts to democratize the society, as a significant majority of museums in the public sectors in the Czech Republic are run by municipalities, followed by regions. An interesting fact is that in the Czech Republic, there are 6,240 municipalities, out of which most municipalities have fewer than 1,000 inhabitants. When it comes to territorial fragmentation, the Czech Republic is similar to Spain and Italy. In the Czech Republic, the local governments are autonomous in establishing institutions of this character.

The following table presents basic data on revenues, expenditures of museums and the level of their economic independence.

\section{Table 2}

Revenues, expenditures and economic independence in the years 2010-2014 in thousands of CZK

\begin{tabular}{|l|r|r|r|r|r|r|}
\hline & $\mathbf{2 0 1 0}$ & $\mathbf{2 0 1 1}$ & $\mathbf{2 0 1 2}$ & $\mathbf{2 0 1 3}$ & $\mathbf{2 0 1 4}$ & $\mathbf{2 0 1 5}$ \\
\hline $\begin{array}{l}\text { Revenues } \\
\text { of galleries, } \\
\text { museums and } \\
\text { monuments }\end{array}$ & 707,075 & 675,606 & 718,215 & 777,060 & 838,047 & 923,384 \\
\hline $\begin{array}{l}\text { From this, } \\
\text { the collected } \\
\text { admission }\end{array}$ & 235,015 & 266,074 & 262,121 & 327,133 & 379,527 & 399,188 \\
\hline $\begin{array}{l}\text { Non-investment } \\
\text { expenses }\end{array}$ & $4,019,608$ & $3,874,071$ & $3,956,811$ & $4,014,756$ & $4,236,940$ & $4,429,465$ \\
\hline $\begin{array}{l}\text { From this, the } \\
\text { purchase of } \\
\text { collection items }\end{array}$ & 54,364 & 51,442 & 43,077 & 49,766 & 54,911 & 49,472 \\
\hline \% self-sufficiency & 17.6 & 17.4 & 18.2 & 19.4 & 19.8 & 20.8 \\
\hline
\end{tabular}

Source: NIPOS (2016)

From the data, it is obvious that expenditures significantly exceed the revenues, and the economic independence is around $19 \%$. Although the trend is slightly positive and there is a gradual improvement, it is obvious that without a strong support from the public budgets, be it state, regional or municipal levels, museums would not be able to work. The financing of museums is realized most often in the form of operational contribution for the individual organizations. Local governments finance this contribution through the revenue of shared taxes.

The following table describes indicators of activity of museums, i.e. the number of prepared displays and exhibits as well as their attendance.

With regards to significant - and in time continuously increasing - attendance, museums are also becoming an important player in the field of tourism in the individual regions. 
Table 3

Indicators of activity of museums

\begin{tabular}{|l|c|c|c|c|c|c|c|}
\hline \multicolumn{1}{|c|}{ Indicator } & \multicolumn{7}{|c|}{ Year } \\
\cline { 2 - 8 } & $\mathbf{1 9 9 5}$ & $\mathbf{2 0 0 0}$ & $\mathbf{2 0 0 5}$ & $\mathbf{2 0 1 0}$ & $\mathbf{2 0 1 3}$ & $\mathbf{2 0 1 4}$ & $\mathbf{2 0 1 5}$ \\
\hline $\begin{array}{l}\text { Number of displays } \\
\text { and exhibitions }\end{array}$ & 3,912 & 4,777 & 5,420 & 5,675 & 6,076 & 6,199 & 4,254 \\
\hline $\begin{array}{l}\text { Number of visitors } \\
\text { to displays and } \\
\text { exhibitions (in } \\
\text { thousands). }\end{array}$ & 8,915 & 9,323 & 9,132 & 9,308 & 10,490 & 11,651 & 11,768 \\
\hline $\begin{array}{l}\text { Number of visitors } \\
\text { per } 1 \text { thousand } \\
\text { inhabitants }\end{array}$ & 863 & 908 & 892 & 885 & 998 & 1,107 & N/A \\
\hline $\begin{array}{l}\text { Number of visitors } \\
\text { per m }{ }^{2} \text { of exhibition } \\
\text { space }\end{array}$ & $\mathrm{X}$ & 12 & 10 & 10 & 11 & 12 & N/A \\
\hline $\begin{array}{l}\text { Total exhibition area } \\
\mathrm{m}^{2}\end{array}$ & $\mathrm{X}$ & 748,203 & 875,127 & 924,564 & 949,026 & 964,163 & N/A \\
\hline
\end{tabular}

Source: NIPOS (2016)

\section{Methods and data}

The main used method is a data envelopment analysis. Data envelopment analysis is therefore a linear programming procedure for the frontier analysis of inputs and outputs. DEA assigns a score of 1 to a unit only when it does not display inefficiencies in the use of inputs and production outputs compared with the relevant units. A score of less than one represents an inefficient unit. This means that the linear combinations of the other units in the sample are capable of producing the same vector output using the same vector inputs. An approach based on the DEA method is not too common in the field of museums, galleries and monuments. As part of the review of the literature, several studies regarding the application of DEA in evaluating the efficiency of museums were found, for example Taheri and Ansari (2013) and Barrio et al. (2009, 259). Barrio et al. (2009) count it among the first and most important applications of this method. The authors applied DEA to assess the technical efficiency of the regional system of museums in Spain. Among the entered variables in the evaluation of technological efficiency were included: the number of employees, size in $\mathrm{m}^{2}$, number of rooms, equipment, winter opening hours, summer opening hours, admission, social impact, collection impact and visitors. This study (Taheri and Ansari 2012) deals with the evaluation of the technical efficiency of regional museums in Tehran. This study analyzes the technical efficiency of nineteen museums with a focus on the history and cultural heritage for the years 2008-2010. Inputs include all the resources required by the organization for its activities, such as the square meters of exhibition area, the number of custodians and the number 
of other workers. Outputs may take into consideration the services provided by the museums at all levels. Some measures of services provided by museums include the total number of visitors, the number of schoolchildren visiting the museum, the number of special temporary exhibitions organized by the museum, the number of congresses organized, and the number of research projects undertaken (Taheri and Ansari 2013, 435).

In this case the authors decided to choose the following variables, as in the authors' opinion they depict the whole range of activities of museums in their complexity. Variables on the input are thus the following: square meters of area of a museum (this variable gives the size of the exhibition area of a museum), number of expositions of a museum, number of employees of a museum, contribution to the operation of the museum by the founder. The contribution to the operation of the museum by founder of museums consists of the difference between total expenditures of a museum and the revenues of a museum (i.e. income from admission, sale of souvenirs, etc.). This reduction was introduced based on the application of Gray entropy, which helps to optimally define the weights of the individual variables. The first model results indicated that if two variables had been used, i.e. total expenditures as an input variable and own revenues of a museum as an output variable, then these variables would have had the biggest weight, since as numbers they reach the highest values and they are connected with the highest level of entropy, while the other variables would have been marginalized in favor of financial indicators. That is the reason why it was decided to create a difference between the total expenditures and own revenues, which enter the model as an input variable.

As variables defining the output of a model the authors have chosen the number of visitors, number of organized exhibitions, number of publications of a museum and number of days open in the given year. These variables describe how this public service is available to customers, how the museum is active and to what extent it tries to have a social impact thanks to publications. The number of visitors represents the attractiveness of a museum.

All of the above-mentioned variables are included in Model 1. Model 2 omits the variable of the contribution of the founder in order to verify the resulting ranking of museums in a situation when cost-minimization strategy is not stressed, which in the authors' presumptions is characteristic for museums that are established by local authorities.

To calculate the relative efficiency, we use a variant of DEA oriented on inputs. The Charnes Cooper and Rhodes Model is called CCR. This model was first introduced in 1978 and assumes returns of scale. The use of a DEA model oriented on inputs was recommended by Barrio and Herrero (2014).

The final results are objectified with the help of structured interviews with directors of the five largest Czech museum institutions (National Technical Museum, National Museum, Prague City Museum, Silesian Museum, National Museum of 
Agriculture). The authors asked the directors of the institutions to briefly comment on the results and first of all the causes of differences in the performance of the individual institutions.

\subsection{Data}

As stated in Table 1, in the Czech Republic there are 378 museums established by central bodies, regions and municipalities. The authors acquired data about 186 units, out of which 22 units were established by the state, 88 museums established by the region, 76 museums established by municipalities. With municipalities, the situation was more complicated, as approximately 159 museums established by towns in the Czech Republic do not have their own legal personality, and they are run either as part of the local authority or as part of a contributory organization whose aim it is to organize cultural events in the municipality. The selected sample is encumbered with a statistical error of $5.13 \%$ on the level of significance of $95 \%$.

The chosen data were gathered in 2015. Data about the area of museums, number of employees, number of expositions, exhibitions, attendance, publication activity, number of days open in a year were received from the National Information and Consulting Centre for Culture, which is a contributory organization of the Ministry of Culture that deals with gathering statistical information about culture. When gathering data, the authors faced a strong unwillingness to share data about the economy of museums. Data about expenditures and revenues had to be gained separately using data-mining technology from the server http://monitor.statnipokladna.cz/, which is an official server of the Ministry of Finance that publishes information about the economy of all state institutions.

\section{Results}

The following tables express results of DEA including descriptive statistics of the individual inputs and outputs. The results are given for the complete collection, as well as for the individual levels of decentralization.

From Table 4 it is obvious that museums established by municipalities reach significantly higher effectiveness than institutions established by the state or regions. In the collection of institutions established by a municipality, there are a lot more units that reach the value of function 1 - in total 20 units, with regions it is 6 units, with institutions established by the state 0 . Between the institutions established by regions and the state, there is also a much bigger difference in performance.

The results were also ranked according to the focus of the institution. Each category is assigned an average reached value of effectiveness. The numbers in brackets give the size of representation of the individual kind of museums in $\%$ of the sample. The official statistics distinguishes the following categories of museums: general (national history), ethnography (ethnology) and anthropology, archeol- 
ogy and history, open-air museums, science and technology, fine arts, other artistic fields, other. The results are shown in Table 5.

Table 4

Comparison of DEA results for the individual levels of decentralized management (Model 1)

\begin{tabular}{|l|c|c|c|c|}
\hline \multicolumn{1}{|c|}{ Statistics } & $\begin{array}{c}\text { DEA complete } \\
\text { collection }\end{array}$ & DEA State & DEA Region & $\begin{array}{c}\text { DEA } \\
\text { Municipality }\end{array}$ \\
\hline Mean value & 0.54 & 0.42 & 0.45 & 0.68 \\
\hline Median & 0.49 & 0.35 & 0.39 & 0.66 \\
\hline Minimum & 0.04 & 0.13 & 0.04 & 0.14 \\
\hline Maximum & 1.00 & 0.89 & 1.00 & 1.00 \\
\hline Standard deviation & 0.27 & 0.25 & 0.23 & 0.27 \\
\hline Variation coefficient & 0.51 & 0.59 & 0.51 & 0.39 \\
\hline Obliqueness & 0.43 & 0.61 & 0.93 & -0.13 \\
\hline Stand. kurtosis & -1.03 & -0.95 & 0.20 & -1.34 \\
\hline $5 \%$ Perc. & 0.17 & 0.13 & 0.16 & 0.29 \\
\hline 95\% Perc. & 1.00 & 0.89 & 1.00 & 1.00 \\
\hline Lower quartile & 0.33 & 0.23 & 0.28 & 0.44 \\
\hline Upper quartile & 0.73 & 0.61 & 0.57 & 1.00 \\
\hline
\end{tabular}

Source: Authors

Table 5

Results ranked according to the focus of the institution

\begin{tabular}{|l|l|l|l|}
\hline \multicolumn{1}{|c|}{ Focus } & \multicolumn{1}{|c|}{ State } & \multicolumn{1}{c|}{ Region } & Municipality \\
\hline General, combined (national history) & $0.342(23 \%)$ & $0.385(69 \%)$ & $0.667(60 \%)$ \\
\hline Ethnography (ethnology) and anthropology & $0.345(9 \%)$ & $0.287(1 \%)$ & $1(1 \%)$ \\
\hline Archeology and history & $(0 \%)$ & $0.319(3 \%)$ & $0.568(5 \%)$ \\
\hline Open-air museums & $0.813(5 \%)$ & $(0 \%)$ & $0.596(1 \%)$ \\
\hline Other & $0.551(23 \%)$ & $1(1 \%)$ & $0.796(9 \%)$ \\
\hline Science and technology & $0.236(9 \%)$ & $0.493(1 \%)$ & $0.660(3 \%)$ \\
\hline Fine arts & $0.293(14 \%)$ & $0.634(24 \%)$ & $0.789(9 \%)$ \\
\hline Other artistic fields & $0.502(18 \%)$ & $(0 \%)$ & $0.539(3 \%)$ \\
\hline
\end{tabular}

Source: Authors

It is clear from the table that municipal museums reach higher effectiveness in all kinds of focus. General museums (national history) are the most numerous within all establishers in the sample; there are significant differences in relative effectiveness. 
The following table present the results of Model 2, i.e. the approach when economic variables do not enter the model.

\section{Table 6}

Comparison of DEA results for the individual levels of decentralized leadership with omitted economic variables

\begin{tabular}{|l|l|l|l|l|}
\hline \multicolumn{1}{|c|}{ Variable } & $\begin{array}{c}\text { DEA complete } \\
\text { collection }\end{array}$ & \multicolumn{1}{|c|}{ DEA state } & \multicolumn{1}{c|}{ DEA region } & $\begin{array}{c}\text { DEA } \\
\text { municipality }\end{array}$ \\
\hline Mean value & 0.462137 & 0.500629 & 0.422217 & 0.496167 \\
\hline Median & 0.4017 & 0.499992 & 0.363618 & 0.41964 \\
\hline Minimum & 0.0417086 & 0.0417086 & 0.0890379 & 0.137266 \\
\hline Maximum & 1 & 0.890334 & 1 & 1 \\
\hline Standard deviation & 0.248231 & 0.253922 & 0.229845 & 0.262656 \\
\hline Variable coefficient & 0.537138 & 0.507205 & 0.544376 & 0.52937 \\
\hline Obliqueness & 0.743044 & 0.001687 & 1.05254 & 0.628162 \\
\hline Stand. spikiness & -0.328992 & -1.07078 & 0.572405 & -0.691847 \\
\hline $5 \%$ Perc. & 0.139502 & 0.0587553 & 0.119141 & 0.143437 \\
\hline 95\% Perc. & 1 & 0.88895 & 1 & 1 \\
\hline Lower quartile & 0.279472824 & 0.30519265 & 0.265112839 & 0.296083214 \\
\hline Upper quartile & 0.612196807 & 0.668834148 & 0.519376915 & 0.655757323 \\
\hline
\end{tabular}

Source: Authors

From the results it is obvious that after the economic variables had been omitted, the differences in relative effectiveness between institutions according to the individual establishers are minimal. In the collection of municipal museums in total 8 units reached value 1 , with museums established by the region it was 5 units, and no units for museums established by the state. After the economic variables had been omitted, also the variability of results of the complete collection increased, as well as inside of the individual groups.

Comparing both models, it can be deduced that the influence of decentralized leadership lies first of all in the choice of "cost minimization strategy" of municipalities. If we abstract from this strategy and do not include variables relating to it into the model and emphasize more the "social impact", differences in relative effectiveness will equalize.

\section{Discussion}

The better effectiveness of institutions established by municipalities may be found, firstly, on the side of inputs, municipal museums having much smaller area, number of employees and costs, yet they do not reach much worse results than museums es- 
tablished by regions and the central government. The following tables offer a comparison of the individual inputs and outputs according to the level of government.

Tables 7, 8 and 9 show mean value, median, maximum, minimum and standard deviation.

Simple observation will tell us that the average costs of municipal museums are lower by $76 \%$ than at other state institutions. If we look at the average number of employees, in comparison with the state, an approximately $90 \%$ difference can be found. This is very similar to the comparison of the size of exhibition areas, where the average values of the state are higher by $82 \%$. If institutions established by municipalities and regions are compared, the most significant differences are seen in comparison of costs, number of employees and the size of exhibition areas. The number of employees and the size of an exhibition area directly influence the labor costs and building-maintenance costs. Another factor of the effectiveness of museums of local governments is economies of scale; the museums that are not assumed to work effectively are a direct part of the local municipal office or a contributory organization that deals with other activities relating to culture.

The directors of large museums that were interviewed do not see the problem in performance, or more precisely do not regard their institutions as performing less. However, they see a problem in system settings of collecting information about performance. The most consensual opinion was this one: "Higher effectiveness of municipal museums is also influenced by the methodology of data collection of two variables that were included in the model - attendance and publications. Large museums understand attendance and the creation of publications differently than small museums. Museum statistics that are provided in the Czech Republic by the Ministry of Culture (data of NIPOS) is unclear in these two parameters, and there is a conflict between understanding by big and small museums. Large state museums count each visitor only once, even though they are in a building where they visit more exhibitions and expositions. Smaller museums use the opportunity that the NIPOS statistics gives them - the statistics understands a visitor as a visitor of expositions and exhibitions. Thus, if a small museum has 2 expositions and 1 exhibition in its exposition hall, it counts the visitor - who sees all the museum - three times. The statistics enables this. Large museums report attendance as referential places of tourism, i.e. if there are 5 expositions and 2 exhibitions in the exhibition hall, the visitor is always counted only once. This misinterpretation of data may be significant with small museums - based on an examination it can be assumed that the attendance of small museums should be divided by approx. 2. Similarly, it works with publications - big museums have the status of a scientific institution, and publication outputs are reported according to a standard that is usual in science and research. The qualitative parameters of publication entering the database NIPOS are not precisely defined and smaller museums then into the statistics apply also publication outputs that do not meet the standard of scientific output. If we assessed 

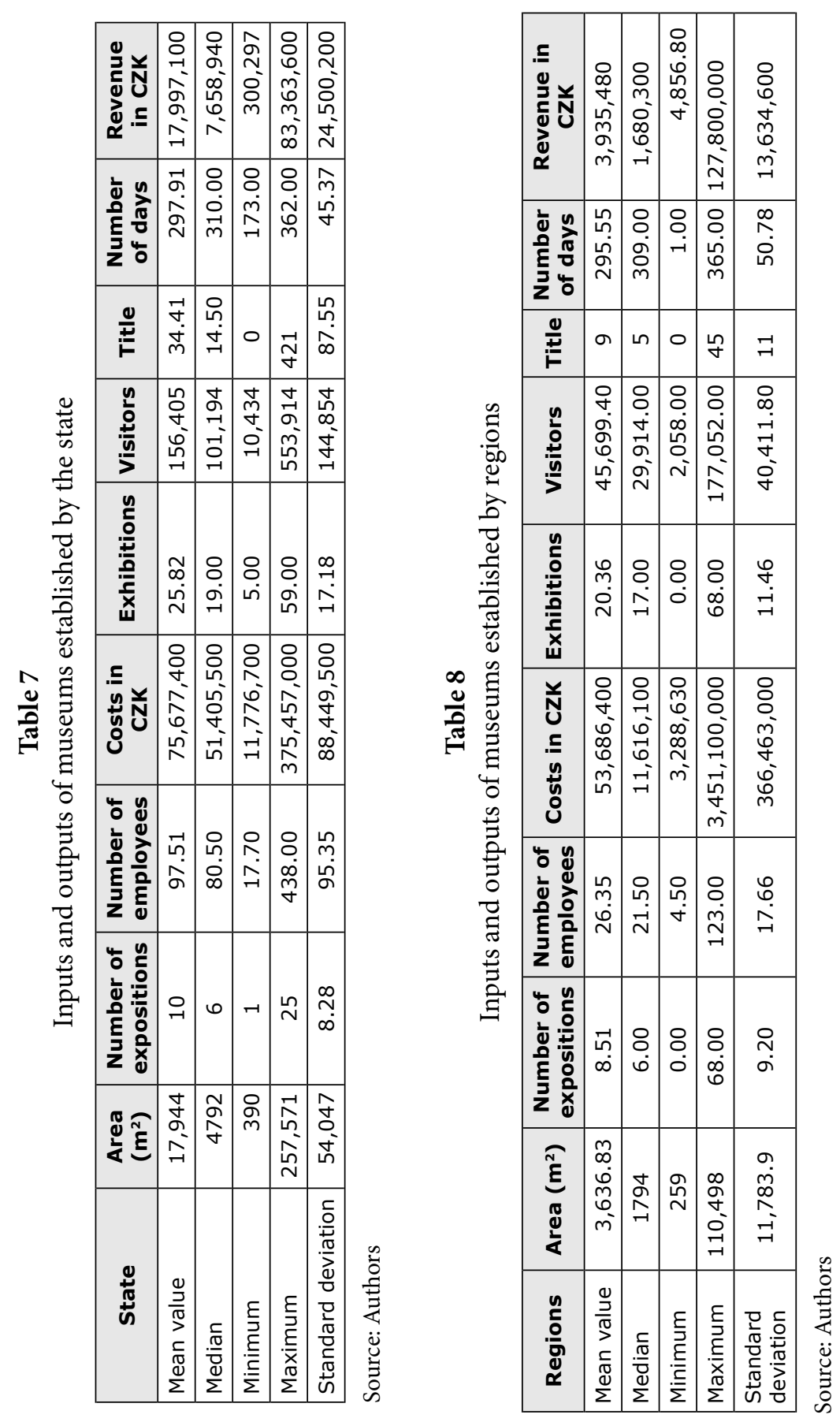


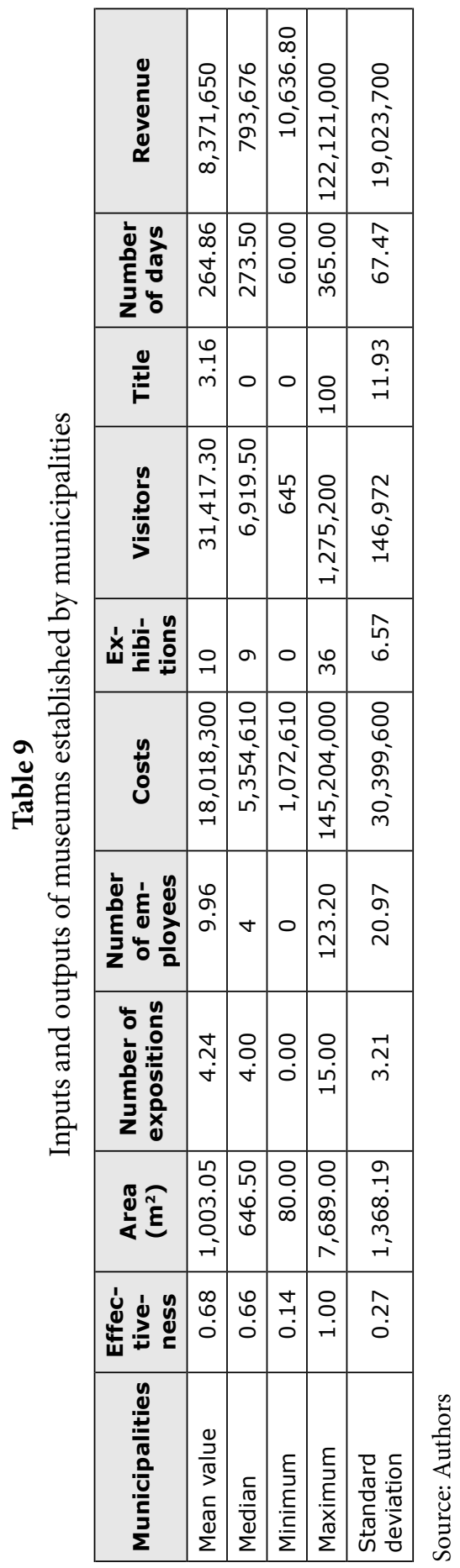


publication outputs of municipal museums according to the same standard as large state museums, municipal museums would not have any results in this field.“

Another argument that the management of big museums mentioned was the question of quality of exhibitions. The consensual opinion was as follows: "It varies case by case. Also small museums have quality expositions and also big museums have old expositions. But from the experience it is true that big museums have more quality, more sophisticated and more up-to-date expositions and exhibitions. There are more people and sources involved."

We must also highlight the fact that some of the variables that enter into the model (visitors and exhibitions) are determined mostly by exogenous factors, such as location, and differences result from the fact that the sample of museums is very heterogeneous and municipal museums are too small when compared to large, national museums as they deal with very little activity.

Results of the examination revealed also peculiarities of the impact of (de) centralization on the effectiveness of museums and economies of scale. Most state museums in the Czech Republic are established centrally. The establisher is the Ministry of Culture. It would be rational to expect that the fact of centralization will manifest in the effect of economies of scale. However, the reality is different. Probably it is the consequence of ("specific") behavior of management of museums in the Czech Republic, as well as the influence of the existing legal framework for the work of museums. The management of museums receives a contribution into their budget from the establisher every year. This has a double impact on the behavior of the management. On one hand, the management of museums work knowing there is some economic certainty for their decision-making, on the other hand, this certainty can lead to opportunistic behavior. This behavior is also encouraged by the fact that the central government or establishers of museums have much higher budgets available, and they provide more activities than the governments on the municipal level. Lower effectiveness of institutions is then not manifested in the budget so significantly as in the case of municipalities in the Czech Republic. This problem in the Czech environment is described by Cernakova (2013) in her study. Managers of museums behave like opportunistic homo agens, i.e. actors whose behavior is influenced by their own intentionality and personal motives. The reserve to reach economies of scale then lies also on the side of the management of museums.

\section{Recommendation for public policy}

As is obvious from the result, the variability of performance according to the individual levels of government is quite high. The biggest gaps in performance can be seen in central and regional institutions due to the lower effectivity of using financial sources. There are a few solutions at hand that may make the whole system more effective. One of them is the centralization of secondary activities on the re- 
gional levels, e.g. sale of tickets, souvenirs, etc. Thus a large potential of economies of scale is created, and if these activities are centralized only on the level of the individual regions, it will not lead to losses from overlaying of competences. This system proved to be right, e.g., in Turkey (Shoup et al. 2014). If we focus on making service activities more effective, the primary function of museums will not be endangered.

With institutions established by the central government, the situation is more complicated because as establishers there are more ministries to which the museums belong, rather due to the functional focus. For instance, the Ministry of Agriculture established the National Agricultural Museum. However, most state museums are established by the Ministry of Culture. In the authors' opinion, it would be good to consider centralization of service activities and thus verify the possibility of reaching economies of scale.

In our opinion, it is necessary, firstly, to explain to management and all relevant stakeholders the importance of implementing performance-measurement systems that can substantiate the argument of limited resources in the field of cultural heritage. The authors recommend for central institutions to introduce compulsory benchmarking. Only centralized institutions would be involved in benchmarking owing to the restrictions of heterogeneity. The implementation of benchmarking would be conducted in two phases. The first phase would focus on service activities such as the operation of buildings, souvenirs, ticket sales, marketing and promotional activities. In this phase, the institution would overcome the initial skepticism regarding this tool and learn to work together. In the second phase, benchmarking would be focused on the core activities of institutions such as fundraising activities, preparation of expositions, organizing educational events and attractions for visitors. As follows from the structured interviews, for benchmarking to be successful, it will be necessary in the first phase to deal with the issue of data quality. The authors report that a benchmarking initiative in this area already exists, but not in a form that the authors propose.

Another important factor is also the increase of civil control. The cultural heritage may be perceived as one of the values "under the protection" that lies beyond the attention of public. It is understood that the function of these institutions cannot be reduced only to the reached economic effectivity; museums fulfill an important function when creating a model regional culture as a publicly provided local public good that increases natives' utility within the region (which generates a "home attachment effect"; Shild and Wrede 2015).

\section{Conclusion}

The article deals with an analysis of the performance of more than 187 museums in the Czech Republic for 2015, and it also examines the influence of decentralized leadership on the reached effectivity. The findings are surprising to a certain extent 
as the best values of technical effectivity are reached by the museums established by the local governments. On the contrary, museums established by the central or regional governments fall behind. The reason for that is mainly the low effectivity of using inputs as opposed to local governments. Even though the Czech Republic is very fragmented territorially, local governments try to use economies of scale. It was possible to prove that the level of decentralized leadership significantly influences the reached effectivity. If the establisher is a regional and central government, there is a decrease of effectivity expressed by the value of the resulting function of data envelopment analysis.

However, if abstracted from financial inputs into the system and focused on the social impact, the kind of establisher statistically does not significantly influence the results of relative effectivity.

To make the current situation better, we suggest to search for gaps in performance first of all with secondary activities and make them more effective in a way so that the primary functions of institutions are not affected.

\section{Acknowledgement}

This work was supported by the internal grant system of the National Museum of Agriculture.

This work was supported by the Grant Agency of the Czech Republic under Grant number GA16-13119S.

\section{References}

Alford, J. and J. O'Flynn. 2009. "Making Sense of Public Value: Concepts, Critiques and Emergent Meanings." International Journal of Public Administration 32(3-4), 171-191.

Atkinson, S. and D. Haran. 2004. "Back to Basics: Does Decentralization Improve Health System Performance? Evidence from Ceara in North-East Brazil." Bulletin of the World Health Organization 82(11), 822-827.

Baraldi, S. B. and D. D. Shoup. 2014. "Heritage Management at the Local Level: Rhetoric and Results in the Case of Gaziantep, Turkey." International Journal of Cultural Policy 20(5), 588-615.

Barrio, J. M. and C. L. Herrero. 2014. "Evaluating the Efficiency of Museums Using Multiple Outputs Evidence from a Regional System of Museums in Spain." International Journal of Cultural Policy 20(2), 221-238. doi:10.1080/102866 32.2013.764290. 
Barrio, J. M., C. L. Herrero and Á. J. Sanz. 2009. "Measuring the Efficiency of Heritage Institutions: A Case Study of a Regional System of Museums in Spain." Journal of Cultural Heritage 10, 258-268.

Benito, B., F. Bastida and J. A. Garcia. 2010. "Explaining Differences in Efficiency: An Application to Spanish Municipalities." Applied Economics 42(4), 515-528. doi:10.1080/00036840701675560.

Caplan, A. J., R. C. Cornes and E. C. D. Silva. 2000. "Pure Public Goods and Income Redistribution in a Federation with Decentralized Leadership and Imperfect Labor Mobility." Journal of Public Economics 77(2), 265-284. doi:10.1016/S0047-2727(99)00102-4.

Cernakova, V. 2013. "Financial Autonomy of Local Governments as a Determinant of Public Services Quality." In V. Klímová and V. Zítek (eds). Proceedings $16^{\text {th }}$ Regional Colloquium of Regional Sciences. Valtice: Masaryk University, 436-443.

Darnell, A., Johnson, P. and Thomas, B. 1998. "The demand for local authority museums: Management issues and hard evidence". Local government studies. 24 (4). pp. 77-94.

De Vries, M. 2000. "The Rise and Fall of Decentralization: A Comparative Analysis of Arguments and Practices in European Countries." European Journal of Political Research 38(2), 19-224. doi:10.1023/A:1007149327245.

Hájek, O., M. Půček and J. Novosák. 2011. "Marketing of Museums: A Case Study of Museums Zlin Region." Časopis Slezského zemského muzea: série B: Vědy historické 60(3), 201-212.

ICOM. 2016. "Code of Ethics for Museums." ICOM. Available at http://www.czmuseums.cz/web/deni_v_oboru/eticky-kodex-muzei (last accessed $17 \mathrm{Au}$ gust 2016).

Marin, R. 2015. "The Local Political Elites in East-Central Europe: Between the Legacy of the Past and the Decentralization of the Present." In A. Jadaneant, C. Tursie, C. Nitu and C. Mesaros (eds). Proceedings of the International Symposium on Ideologies, Values and Political Behaviors in Central and Eastern Europe, $12^{\text {th }}$ Edition. Procedia Social and Behavioral Sciences. Timisoara, Romania: Elsevier, 30-39.

Matějová, L., M. Plaček, M. Křápek, M. Půček and F. Ochrana. 2014. "Economies of Scale: Empirical Evidence from the Czech Republic." Proceedia Economics and Finance, $17^{\text {th }}$ International Conference Enterprise and Competitive Enviroment 2014 12, 403-411. doi:10.1016/S2212-5671(14)00361-X. 
Mazouz, B., A. Rousseau and P. A. Hudon. 2016. "Strategic Management in Public Administrations: A Results-Based Approach to Strategic Public Management." International Review of Administrative Sciences 82(3), 411-417. doi:10.1177/0020852316655522.

Moore, M. and S. Khagram. 2004. "On Creating Public Value: What Business Might Learn from Government About Strategic Management." Working paper of the Corporate Social Responsibility Initiative, Kennedy School of Government. Cambridge, MA: Harvard University.

Nemec, J., B. Meričková and J. Štrangfeldová. 2010. “The Ownership Form of Hospitals from the Viewpoints of Economic Theory and Slovak Practice." $E+M$ : Economics and Management 13(2), 19-31.

NIPOS. 2016. "Culture Czech Republic in Numbers for Year 2015." NIPOS. Available at http://www.nipos-mk.cz/wp-content/uploads/2013/05/Kultura_v_ cislech_2016_web.pdf (last accessed 17 August 2016).

Palermo, F. and A. Wilson. 2014. "The Multi-Level Dynamics of State Decentralization in Italy." Comparative European Politics 12(4-5), 510-530. doi:10.1057/cep.2014.11.

Plaček, M., M. Půček, F. Ochrana and M. Křápek. 2016. "Application of DEA Method for Evaluating Efficiency of Museums, Galleries, and Monuments in the Czech Republic." In J. Krajíček, J. Nešleha and K. Urbanovský (eds). Proceedings of the $13^{\text {th }}$ International Conference European Financial Systems. Brno, Masaryk University, 596-602,

Rutgers, M. R. 2015. "As Good as it Gets? On the Meaning of Public Value in the Study of Policy and Management." American Review of Public Administration 45(1), 29-45. doi:10.1177/0275074014525833.

Schild, Ch.-J. and M. Wrede. 2015. "Cultural Identity, Mobility and Decentralization." Journal of Comparative Economics 43(2), 323-333. doi:10.1016/j. jce.2014.05.002.

Shoup, D. D., S. B. Baraldi and L. Zan. 2014. "A Centralized Decentralization: Outsourcing in the Turkish Cultural Heritage Sector." International Journal of Cultural Policy 20(1), 54-77. doi:10.1080/10286632.2012.731051.

Silva, E. C. D. 2016. “Decentralized leadership." Cesifo Working Paper 6064. Munich.

Silva, E. C. D. 2015. "Efficient Earmarking under Decentralized Fiscal Commitments." International Tax and Public Finance 22, 683-701.

Silva, E. C. D. 2014. "Selective Decentralized Leadership." Journal of Urban Economics $83,1-5$. 
Soukopová, J., J. Nemec, L. Matějová and M. Struk. 2014. "Municipality Size and Local Public Services: Do Economies of Scale Exist?” NISPAcee Journal of Public Administration and Policy 7(2), 151-171. doi:10.2478/nispa-2014-0007.

Taheri, H. and S. Ansari. 2013. "Measuring the Relative Efficiency of Cultural-Historical Museums in Tehran: DEA Approach." Journal of Cultural Heritage 14, 431-438. http://dx.doi.org/10.1016/j.culher.2012.10.006.

Thompson, F. and P. Rizova. 2015. "Understanding and Creating Public Value: Business is the Engine, Government the Flywheel (and also the Regulator)." Public Management Review 17(4), 565-586. doi:10.1080/14719037.2013.841982. 